\title{
Phytotoxicity of Copper-Based Bactericides to Peach and Nectarine
}

\author{
N. Lalancette and K. A. McFarland, Rutgers University, Agricultural Research and Extension Center, Bridgeton, \\ NJ 08302-5919
}

\begin{abstract}
Lalancette, N., and McFarland, K. A. 2007. Phytotoxicity of copper-based bactericides to peach and nectarine. Plant Dis. 91:1122-1130.

Organometallic copper, consisting of a mixture of copper abietate, copper linoleate, and copper oleate (CuALO), is important for postbloom management of bacterial spot in New Jersey peach and nectarine orchards. Rotation of CuALO with oxytetracycline reduces cost and helps prevent (or delay) resistant organisms. However, because copper is also phytotoxic, higher rates and inorganic coppers have not been utilized. A study was conducted on 'Encore' peach and 'Redgold' nectarine to determine the quantitative relationship between copper concentration (metallic equivalent) and phytotoxicity. Different rates of $\mathrm{CuALO}$ and copper hydroxide $(\mathrm{CuOH})$ were applied seven times postbloom. Foliar injury and defoliation increased with number of applications and copper concentration. Maximum 'Encore' defoliation was 10 to $17 \%$, while 'Redgold' sustained 30 to $35 \%$ leaf loss. $\mathrm{CuOH}$ caused similar or less leaf injury and defoliation than CuALO. No injury was observed on fruit, even at three times the labeled metallic copper rate of CuALO. Fruit size and soluble solids were not influenced by copper. Estimates of foliar density and tree volume indicated that sufficient photosynthetic capacity existed to allow acceptable leaf damage and loss from copper applications. These results showed that inorganic coppers may be viable alternatives to organometallic copper for postbloom bacterial spot control; nectarine may be more sensitive to copper injury than peach; and higher rates of metallic copper, above the current commercial rate, can be applied to peach. In the latter case, greater amounts of copper may provide longer residual activity and improved bacterial spot control on highly susceptible cultivars.
\end{abstract}

Additional keywords: Xanthomonas arboricola pv. pruni

Bacterial spot of stone fruit, caused by Xanthomonas arboricola pv. pruni, is one of the most important bacterial diseases of peach (Prunus persica (L.) Batsch.) and nectarine (Prunus persica (L.) Batsch var. nucipersica (Suckow) C.K. Schneid.) in the eastern United States (1,15). Significant foliar infection, which results in the formation of brown to black angular lesions, often causes premature defoliation. Infection of twigs, which results in canker formation, allows the pathogen to overwinter between growing seasons. Fruit infection results in the development of lesions, gumming, and cracking. When environmental conditions are favorable for disease development, significant crop loss can occur.

Disease resistance is an important component of bacterial spot management (15). However, no cultivars are totally immune (24), and many favored by producers for their horticultural or marketing characteristics are highly susceptible. Consequently, bactericides are often required,

Corresponding author: N. Lalancette

E-mail: lalancette@aesop.rutgers.edu

Accepted for publication 30 March 2007.

doi:10.1094/PDIS-91-9-1122

(C) 2007 The American Phytopathological Society but the choice is limited to the antibiotic oxytetracycline or copper-based compounds (15). Oxytetracycline can be effective, but its successful use requires accurate timing in relation to infection, high spray volumes for complete coverage, and application to every tree row as opposed to every other row (alternatemiddle row spraying). Furthermore, the antibiotic is expensive and lacks long residual activity, and there is concern about the development of pathogen resistance.

In contrast to antibiotics, copper-based bactericides are relatively inexpensive and have fewer application requirements for successful use. The amount of actual copper in these bactericides, expressed on a percentage by weight basis, is called "metallic copper". The cupric ion $\left(\mathrm{Cu}^{2+}\right)$, which is released upon dissociation, is the active ingredient and inhibits bacterial growth at low concentrations (4). However, since copper is also phytotoxic to peach and nectarine, the amount of material that can be applied is limited (15). Nevertheless, application rates need to be as high as possible for lasting, effective residual activity, but not so high as to cause significant plant damage or yield loss. Currently, little is known about the relationship between copper concentration (metallic or ionic) and the degree of phytotoxicity on stone fruit.

New Jersey growers routinely apply the copper compound Tenn-Cop 5E (copper salts of fatty and rosin acids; Miller Chemical and Fertilizer Corp., Hanover, PA) to peaches throughout the growing season for bacterial spot management. The general belief is that this organometallic bactericide is less phytotoxic than the various inorganic copper compounds, such as copper hydroxide or basic copper sulfate. However, no data are available that demonstrate that these two different classes of copper-based compounds, when applied at the same metallic copper concentration, differ in their phytotoxicity. Furthermore, prior to the start of the 2003 growing season, regulatory and manufacturing issues resulted in either low or unavailable supplies of both oxytetracycline and TennCop, leaving growers with few chemical control choices for bacterial spot management. Lack of information on the crop safety of the inorganic copper-based bactericides prevented their use for disease control, particularly during the postbloom period.

In contrast to peach, Tenn-Cop has only been used sparingly on nectarine by commercial New Jersey growers. In pome fruit production, copper-based compounds have been shown to russet the fruit of certain apple and pear cultivars $(13,21)$. Thus, there is concern that these materials may similarly damage the smooth epidermis of nectarine fruit. However, once again, no data are available to demonstrate if copperbased bactericides are injurious to the nectarine fruit surface. Consequently, bacterial spot control on the many susceptible nectarine cultivars has been mainly limited to application of the antibiotic oxytetracycline.

The overall goal of this study was to increase knowledge on the phytotoxicity of copper-based bactericides to stone fruit. Specific objectives were: (i) describe the observed types of injury to foliage and fruit; (ii) determine the relationship between metallic copper concentration and phytotoxicity; (iii) ascertain any differences in copper sensitivity between peach and nectarine, with particular attention to fruit finish; and (iv) compare phytotoxicity of organometallic and inorganic copper compounds. Preliminary findings have been previously reported (10).

\section{MATERIALS AND METHODS}

Orchard sites. 'Encore' peach and 'Redgold' nectarine orchards, planted at $7.6 \times 7.6 \mathrm{~m}$ tree spacing, were selected for the study conducted during the 2002 and 2003 growing seasons. Both orchards, 
located at the Rutgers Agricultural Research and Extension Center, were 5 years old in 2002 and did not have any significant levels of bacterial spot since planting. The absence of bacterial spot was necessary in order to obtain an accurate assessment of phytotoxicity since two important disease symptoms, foliar shotholing and defoliation, also result from copper injury. Weather data were recorded during the study using a $21 \mathrm{X}$ data logger (Campbell Scientific, Inc., Logan, UT) located approximately $200 \mathrm{~m}$ north of the two orchards. Air temperature, relative humidity, rainfall, and solar radiation observations were recorded every minute from logger sensors and summarized on an hourly basis.

Treatments. The experimental design within each orchard consisted of a randomized complete block with four replicate trees per treatment. To allow direct comparison of different types of copper-based bactericides, application rates for each treatment were based on the amount of actual copper in the bactericide, also referred to as "metallic copper" $\left(\mathrm{Cu}_{\mathrm{m}}\right)$. The current recommended application rate range for Tenn-Cop 5E (51.5 $\mathrm{g} \mathrm{Cu}_{\mathrm{m}} /$ liter), which consists of a mixture of copper abietate, copper linoleate, and copper oleate (CuALO), was 292.3 to $584.6 \mathrm{ml} / \mathrm{ha}$ $(5,19)$. In terms of active ingredient, this rate range translated to 15.1 to $30.2 \mathrm{~g}$ $\mathrm{Cu}_{\mathrm{m}} /$ ha, respectively.

In 2002, six different copper treatments consisting of CuALO at 15.1, 30.2, 60.4, and $90.6 \mathrm{~g} \mathrm{Cu} / \mathrm{ma}$, copper hydroxide $(\mathrm{CuOH})$ at $90.6 \mathrm{~g} \mathrm{Cu}_{\mathrm{m}} / \mathrm{ha}$ (Champ Formula 2 Flowable; $359.5 \mathrm{~g} \mathrm{Cu}_{\mathrm{m}} /$ liter; NuFarm Americas, Inc., Burr Ridge, IL), and copper oxychloride $(\mathrm{CuOC})$ at $90.6 \mathrm{~g} \mathrm{Cu}_{\mathrm{m}} / \mathrm{ha}$ (Microsperse COC 53WP; $530 \mathrm{~g} \mathrm{Cu}_{\mathrm{m}} / \mathrm{kg}$; Micro Flo Co., Memphis, TN) were applied to the 'Encore' peach trees. In 2003, the same treatments were reapplied in this orchard except that the $15.1 \mathrm{~g} \mathrm{Cu}_{\mathrm{m}} /$ ha rate of $\mathrm{CuALO}$ was replaced with a $30.2 \mathrm{-g}$ $\mathrm{Cu}_{\mathrm{m}} /$ ha rate of $\mathrm{CuOH}$. Eight different copper treatments, consisting of the same four rates of $\mathrm{CuALO}$, three rates of the $\mathrm{CuOH}$ (30.2, 60.4, and $\left.90.6 \mathrm{~g} \mathrm{Cu}_{\mathrm{m}} / \mathrm{ha}\right)$, and one rate of $\mathrm{CuOC}\left(90.6 \mathrm{~g} \mathrm{Cu}_{\mathrm{m}} / \mathrm{ha}\right)$ were applied to the 'Redgold' nectarine trees in both 2002 and 2003. Nontreated trees served as the controls.

Beginning at shuck-off (calyx detached from fruit), treatments were applied at 8to 15-day intervals for a total of seven applications. Application dates in 2002 were 6 May, 16 May, 31 May, 13 June, 25 June, 8 July, and 16 July. Applications in 2003 , much delayed by a cold spring, were on 29 May, 9 June, 23 June, 2 July, 11 July, 21 July, and 31 July. All materials were applied using a Rears Pak-Blast-Plot airblast sprayer (Rears Manufacturing Co., Eugene, OR) at 935 liters/ha volume; 690 $\mathrm{kPa}$ pressure; and $3.4 \mathrm{~km} / \mathrm{h}$ tractor speed. Nonsprayed buffer trees surrounded each treatment tree to minimize interplot interference from spray drift. The fungicide azoxystrobin (Abound 2.08F; Syngenta Crop Protection, Greensboro, NC) was applied to all trees at late petal fall and shuck-split to control peach scab; tebuconazole (Elite 45DF; Bayer CropScience, Research Triangle Park, NC) was applied preharvest to control brown rot. The insecticides azinphosmethyl (Guthion 50WP, Bayer CropScience), imidacloprid (Provado 1.6F, Bayer CropScience), phosmet (Imidan 70W, Gowan Company, Yuma, AZ), and spinosad (Spintor 2SC, Dow AgroSciences, Indianapolis, IN) were applied according to commercial recommendations using an airblast sprayer (5).

Assessment. To monitor phytotoxicity on foliage in each year of the study, six current season vegetative shoots were arbitrarily selected and tagged around the periphery of each treatment tree. Injury assessments on these shoots were conducted on 23 May, 30 May, 14 June, 27 June, 10 July, and 19 July during 2002 and on 30 May, 5 June, 18 June, 30 June, 15 July, 25 July, and 6 August in 2003. During each assessment, the total numbers of leaves present and missing (abscised) were recorded for each tagged shoot. Of those leaves present, the number of leaves with copper injury spots and shot-holes was also recorded (described in results). Given these observations on foliage, two dependent variables were calculated: \% injured leaves and $\%$ abscised leaves.

Phytotoxicity to fruit was examined on both cultivars at harvest on 21 to $23 \mathrm{Au}$ gust 2002 and 18 August 2003 on 'Redgold', and 11 September 2003 on 'Encore'. A total of 50 fruit were arbitrarily sampled from each tree. To evaluate the impact of copper treatments on fruit growth, individual fruit diameter and weight measurements were taken. To determine if copper was influencing fruit finish, fruit were classified according to type of visible injury. Fruit were placed into six different fruit finish categories: scarring, russet, stipple, netting, off color, and unblemished. In 2003, percent soluble solids were also measured for harvested 'Encore' fruit using a Leica AR200 digital refractometer (Leica Microsystems Inc., Buffalo, NY).

Phytotoxicity to current season vegetative shoot growth was also examined in the study. During the fall following each growing season, 10 shoots were arbitrarily selected around the periphery of each tree. The length of each shoot, measured from the terminal bud scale scar to the growing tip, was recorded. The total number of leaf nodes for this same shoot section was also counted and recorded for analysis.

Allowable defoliation. In order to determine the influence of defoliation from copper on the foliage-fruit load relationship, an estimate of the total number of leaves on healthy, noninjured trees was needed. This number was calculated from a combination of tree volume and foliar density measurements. The four nontreated trees in each orchard were used for these measurements.

To estimate tree volume, the dimensions of each tree were measured after termination of shoot growth (late July or early August). Tree measurements consisted of length parallel to the row $(l)$, width perpendicular to the row $(w)$, and height $(h)$ from the bottom to the top of the canopy. These data were used to calculate tree volume $(V)$ using the formula for an ellipsoid, where $V=4 / 3 \pi(l / 2)(w / 2)(h / 2)$. To determine foliar density, an open-faced cube constructed of plastic tubing, measuring $45 \mathrm{~cm}$ on each side, was randomly placed within the tree canopy. Exact location of the cube was determined by randomly selected coordinates for each dimension that were within the sets $[0, l],[0$, $w]$, and $[0, h]$. Once placed within the canopy, the number of leaves that fell naturally within the cube was counted; this value, along with the cube's volume, were used to calculate foliar density at the given location. A total of 24 observations, or six cube measurements per tree, were taken in each orchard; a preliminary study showed that the variance stabilized after approximately 16 observations ( 4 trees $\times 4$ observations/tree). From these data, the total number of leaves $(L)$ on each tree was estimated using the formula $L=V \times D_{m}$, where $D_{m}$ represents the mean of the six foliar density observations per tree.

Allowable defoliation $\left(D E F_{a}\right)$, defined as the percentage of leaves that can abscise without influencing fruit size for a given fruit load, was calculated using the formula $D E F_{a}=[L-(F L \times L F R)] / L \times 100$, where $F L$ is the desired fruit load or target number of fruit to harvest per tree, and $L F R$ is the leaf:fruit ratio. $D E F_{a}$ values were calculated for all orchards assuming trees were thinned to $F L=600$ fruit and $L F R=30,40$, and 50 leaves per fruit. Past horticultural experimentation and recommendations have indicated that approximately 30 to 50 leaves are needed to grow a single peach $(3,8,11,23,25)$. The resulting hypothetical estimates of allowable defoliation were compared with experimental defoliation levels observed on treatment trees treated with different rates of copperbased bactericides.

Statistical analysis. Since multiple observations were made for each foliar dependent variable over time, areas under the resulting injury (AUIC) and defoliation (AUDC) curves were calculated for each experimental replicate. Separate analyses of variance (ANOVA) were then performed on these area means for each cultivar using the GLM procedure of the Statistical Analysis System v8.2 (SAS Institute, Cary, NC). Similarly, separate ANOVAs were performed on fruit diameter, fruit weight, fruit injury categories, soluble 
solids, and shoot length data for each orchard. All mean comparisons were conducted using the Waller-Duncan $k$-ratio $t$ test $(\alpha=0.05 ; k=100)$.

\section{RESULTS}

Foliar injury. Copper-based bactericide injury to leaves began with the appearance of light green areas that quickly evolved into reddish-brown spots. Unlike angular, interveinal bacterial spot lesions (1), these spots were circular or irregular in shape and were not restricted by leaf veins. Eventually, the necrotic centers of the spots detached and fell away, creating a "shot-hole" appearance. Some severely injured leaves displayed curling and reddening, particularly on their abaxial surface. Leaves sustaining much injury often became chlorotic, particularly along the veins. Older leaves were the first to turn chlorotic and abscise. Thus, defoliation progressed from the base of the shoot toward the growing point. The types of injury observed on foliage were nearly identical for both the 'Redgold' nectarine and 'Encore' peach.

In general, the application of higher rates of metallic copper, regardless of the type of copper compound, resulted in higher levels of injury (Fig. 1). Also, for any given bactericide and rate of application, the percentage of injured leaves was greater for 'Redgold' nectarine than it was for 'Encore' peach. For example, by the third assessment in 2003, foliar injury from $\mathrm{CuOH}$ at $30.2 \mathrm{~g} \mathrm{Cu}_{\mathrm{m}}$ /ha was $25.5 \%$ injured leaves on 'Redgold', but only $4.3 \%$ on 'Encore' (Fig. 1B and D). Finally, for each cultivar, the levels of injury sustained in 2003 were greater than observed in 2002.

Substantial amounts of foliar injury were observed immediately after the first or second application of copper-based bactericides (Fig. 1). However, for any given treatment, the percentage of injured leaves did not vary appreciably as additional applications were made throughout the summer. Most foliar injury progression curves showed only a slight increase in leaf spotting from the time of the first or second assessment onward. This phenomenon was particularly evident for both cultivars in 2002 and on 'Redgold' in 2003 (Fig. 1A, C, and D). Although older leaves were constantly being injured and defoli-
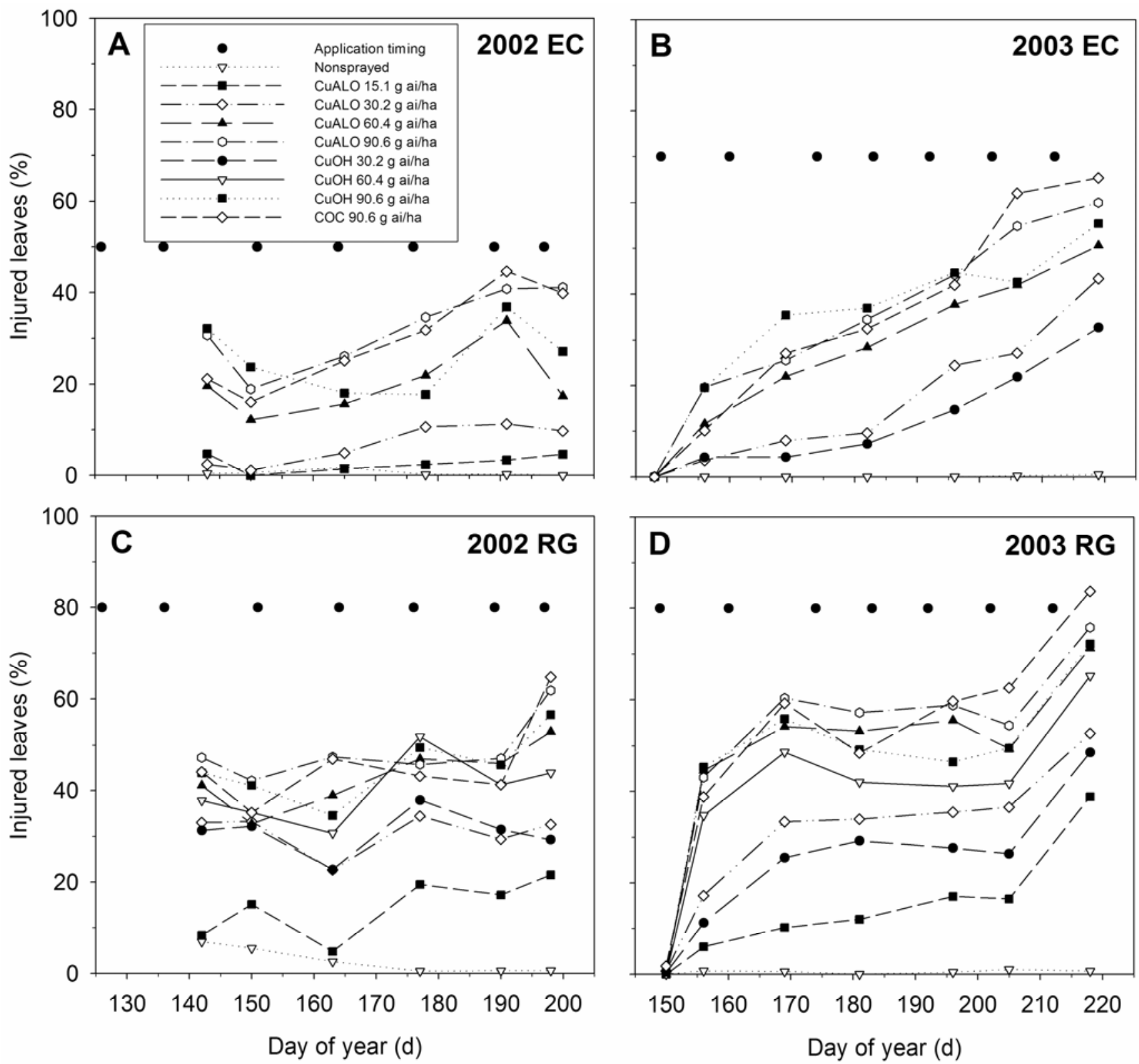

Fig. 1. Progression of foliar injury over time for A and B, 'Encore' peach (EC), and C and D, 'Redgold' nectarine (RG) trees treated with consecutive applications of three types of copper-based bactericides (solid dots) during two growing seasons. Leaves were assessed as injured if one or more burn spots were present; abscised leaves were not included in the assessment. All bactericides were applied at 935 liters/ha via an airblast sprayer beginning at shuck-off. Data are means of 4 replicate trees with 6 shoots/tree. 
ated, enough newer leaves were being formed to maintain a balanced proportion of injured and uninjured leaves.

The importance of new leaf formation was apparent on 'Redgold' in 2003. When shoots set their terminal buds in late July (days 205 to 220), thus halting production of leaves, a dramatic increase in the percentage of injured leaves was observed between the last two assessments (Fig. 1D). Similarly, the gradual increase in percentage of injured leaves on 'Encore' in 2003 was a result of a lower rate of leaf production in that year (Fig. 1B). In 2002, a mean 46.4 leaves/shoot were observed by day 200 , while only 38.3 leaves/shoot were formed by this date in 2003. Thus, the rate at which 'Encore' leaves were becoming injured in 2003 outpaced the rate at which they were being produced.
Unlike foliar injury, dramatic increases in leaf abscission were not evident on 'Encore' after the initial one or two applications of copper-based bactericides (Fig. 2A and B). On this peach cultivar, most treatments caused only a gradual increase in defoliation as additional sprays were applied throughout the summer. In both years, maximum defoliation ranged from approximately 10 to $15 \%$ of leaves abscised by days 200 to 220 . The only exception was for CuALO at the highest rate in 2002, which appeared somewhat more phytotoxic.

In contrast to 'Encore' peach, much higher levels of defoliation occurred on 'Redgold' nectarine in both years of the study (Fig. 2C and D). Abscission of leaves was much more evident after the initial bactericide applications in late spring. Furthermore, both type of copperbased bactericide and rate of application substantially influenced the defoliation response. For example, by day 218 in $2003,35.8 \%$ of leaves were defoliated on trees that received CuALO at $90.6 \mathrm{~g}$ $\mathrm{Cu}_{\mathrm{m}} /$ ha, while only $5.7 \%$ were abscised from trees treated with the same bactericide at $15.1 \mathrm{~g} \mathrm{Cu}_{\mathrm{m}} / \mathrm{ha}$.

Some defoliation was observed on nontreated trees of both cultivars in each year. The exact cause of this leaf loss was unknown. Since older leaves were observed to be missing, it may be due to normal leaf senescence or perhaps leaf drop from early-season infections by Taphrina deformans. Nevertheless, leaf abscission on nontreated shoots generally remained below $10 \%$ throughout the study (Fig. 2). This background level of
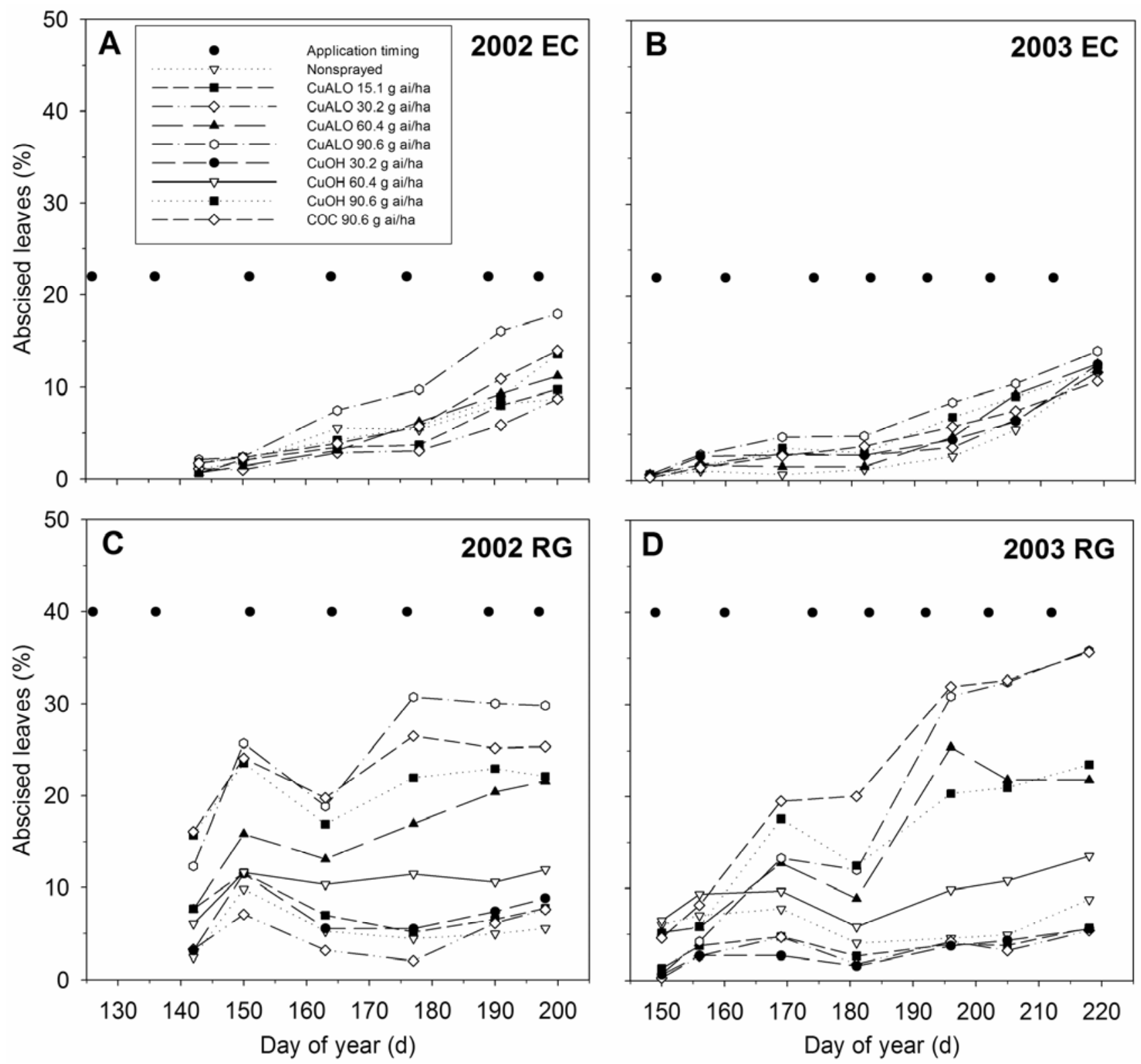

Fig. 2. Progression of defoliation over time for $\mathbf{A}$ and $\mathbf{B}$, 'Encore' peach (EC), and $\mathbf{C}$ and $\mathbf{D}$, 'Redgold' nectarine (RG) trees treated with consecutive applications of three types of copper-based bactericides (solid dots) during two growing seasons. Abscised leaves were assessed by counting the number of leaf nodes. All bactericides were applied at 935 liters/ha via an airblast sprayer beginning at shuck-off. Data are means of 4 replicate trees with 6 shoots/tree. 
defoliation most likely occurred on all treatments.

Comparison of areas under progression curves. All ANOVA models and treatment main effects for fitting the AUIC and AUDC dependent variables were statistically significant (Table 1). For each cultivar, the year main effect was significant for the AUIC data, but not for the AUDC data. Thus, although the overall amount of foliar injury was greater in 2003 and significantly different from that observed in 2002, this difference did not translate into significantly greater levels of defoliation in 2003. var revealed significant increases in injury as the rate of application of CuALO or $\mathrm{CuOH}$ increased (Table 2). However, more importantly, no significant differences in injury were detected between CuALO,
Analysis of AUIC means for each culti-

$\mathrm{CuOH}$, and $\mathrm{COC}$ when applied at the same rates of 30.2 or $90.6 \mathrm{~g} \mathrm{Cu}_{\mathrm{m}}$ per hectare. The one exception occurred on 'Redgold' at the $60.5 \mathrm{-g}$ rate, in which trees treated with $\mathrm{CuOH}$ had significantly less injury than those treated with CuALO. Although the experimental design precluded a direct statistical comparison of the two cultivars, the AUIC values for 'Redgold' were consistently higher than their corresponding 'Encore' values for each treatment in the study.

The low level of defoliation observed on the 'Encore' trees was quite evident in the statistical comparison of the AUDC means (Table 2). Six of the seven copper treatments had AUDC means that were not significantly different from that of the nontreated control. Only 'Encore' trees treated with CuALO at the high $90.6 \mathrm{~g}$ $\mathrm{Cu}_{\mathrm{m}} /$ ha rate had significantly more defolia-

Table 1. Analysis of variance of areas under the injury (AUIC) and defoliation (AUDC) curves describing phytotoxicity of various copper-based bactericide treatments to peach and nectarine

\begin{tabular}{|c|c|c|c|c|c|}
\hline $\begin{array}{l}\text { Cultivar } \\
\text { Variable }\end{array}$ & Source & df & $\begin{array}{c}\text { Mean } \\
\text { square }\end{array}$ & $F$ value & $P>F$ \\
\hline \multicolumn{6}{|l|}{ 'Encore' } \\
\hline \multirow[t]{5}{*}{ AUIC } & Model & 11 & $4.01 \times 10^{6}$ & 33.93 & $<0.0001$ \\
\hline & Year & 1 & $7.57 \times 10^{6}$ & 64.12 & $<0.0001$ \\
\hline & Treatment & 7 & $5.17 \times 10^{6}$ & 43.74 & $<0.0001$ \\
\hline & Replicate & 3 & $1.17 \times 10^{5}$ & 0.99 & 0.4076 \\
\hline & Error & 44 & $1.18 \times 10^{5}$ & & \\
\hline \multirow[t]{5}{*}{ AUDC } & Model & 11 & $4.01 \times 10^{4}$ & 2.32 & 0.0238 \\
\hline & Year & 1 & $6.60 \times 10^{2}$ & 0.04 & 0.8458 \\
\hline & Treatment & 7 & $5.16 \times 10^{4}$ & 2.99 & 0.0118 \\
\hline & Replicate & 3 & $2.63 \times 10^{4}$ & 1.53 & 0.2212 \\
\hline & Error & 44 & $1.73 \times 10^{4}$ & & \\
\hline \multicolumn{6}{|l|}{ 'Redgold' } \\
\hline \multirow[t]{5}{*}{ AUIC } & Model & 12 & $6.92 \times 10^{6}$ & 42.02 & $<0.0001$ \\
\hline & Year & 1 & $7.22 \times 10^{6}$ & 43.84 & $<0.0001$ \\
\hline & Treatment & 8 & $9.34 \times 10^{6}$ & 56.76 & $<0.0001$ \\
\hline & Replicate & 3 & $3.44 \times 10^{5}$ & 2.09 & 0.1111 \\
\hline & Error & 59 & $1.65 \times 10^{5}$ & & \\
\hline \multirow[t]{5}{*}{ AUDC } & Model & 12 & $1.26 \times 10^{6}$ & 19.20 & $<0.0001$ \\
\hline & Year & 1 & $1.68 \times 10^{1}$ & 0.01 & 0.9873 \\
\hline & Treatment & 8 & $1.86 \times 10^{6}$ & 28.29 & $<0.0001$ \\
\hline & Replicate & 3 & $8.97 \times 10^{4}$ & 1.36 & 0.2627 \\
\hline & Error & 59 & $6.58 \times 10^{4}$ & & \\
\hline
\end{tabular}

Table 2. Comparison of postbloom applications of organometallic and inorganic copper-based bactericides for their ability to induce foliar injury and defoliation of 'Encore' peach and 'Redgold' nectarine

\begin{tabular}{|c|c|c|c|c|c|}
\hline \multirow[b]{2}{*}{ Bactericide $^{x}$} & \multirow[b]{2}{*}{$\left(\mathrm{g} \mathrm{Cu}_{\mathrm{m}} / \mathbf{h a}\right)^{\mathrm{y}}$} & \multicolumn{2}{|c|}{ AUIC $^{w}$} & \multicolumn{2}{|c|}{ AUDC $^{w}$} \\
\hline & & 'Encore' & 'Redgold' & 'Encore' & 'Redgold' \\
\hline Nontreated & 0.0 & $21 \mathrm{~d}$ & $85 \mathrm{e}$ & $256 \mathrm{~b}$ & $360 \mathrm{~d}$ \\
\hline \multirow[t]{4}{*}{ CuALO } & 15.1 & $123 \mathrm{~d}^{\mathrm{z}}$ & $886 \mathrm{~d}$ & $252 b^{z}$ & $337 \mathrm{~d}$ \\
\hline & 30.2 & $775 \mathrm{c}$ & $1,950 \mathrm{c}$ & $244 \mathrm{~b}$ & $241 \mathrm{~d}$ \\
\hline & 60.4 & $1,605 \mathrm{~b}$ & $2,925 \mathrm{a}$ & $300 \mathrm{~b}$ & $968 \mathrm{~b}$ \\
\hline & 90.6 & $2,160 \mathrm{a}$ & $3,182 \mathrm{a}$ & $497 \mathrm{a}$ & $1,377 \mathrm{a}$ \\
\hline \multirow[t]{3}{*}{$\mathrm{CuOH}$} & 30.2 & $838 c^{z}$ & $1,744 \mathrm{c}$ & $310 b^{z}$ & $303 \mathrm{~d}$ \\
\hline & 60.4 & $\ldots$ & $2,561 \mathrm{~b}$ & $\ldots$ & $616 c$ \\
\hline & 90.6 & $1,967 \mathrm{a}$ & $2,904 \mathrm{ab}$ & $346 \mathrm{ab}$ & $1,125 \mathrm{~b}$ \\
\hline $\mathrm{COC}$ & 90.6 & $2,112 \mathrm{a}$ & $3,085 \mathrm{a}$ & $335 \mathrm{ab}$ & $1,443 \mathrm{a}$ \\
\hline
\end{tabular}

${ }^{\mathrm{w}}$ Analysis conducted on combined 2002 and 2003 injury and defoliation data as represented in Figures

1 and 2 , respectively. Area values assigned the same letter in any one column are not significantly different according to the Waller-Duncan $k$-ratio $t$ test $(\alpha=0.05 ; k=100)$.

${ }^{x} \mathrm{CuALO}=$ copper abietate + copper linoleate + copper oleate $($ Tenn-Cop $5 \mathrm{E}) ; \mathrm{CuOH}=$ copper hydroxide (Champ Formula 2); and COC = copper oxychloride (Microsperse COC 53WP).

${ }^{\mathrm{y}} \mathrm{g} \mathrm{Cu}_{\mathrm{m}} / \mathrm{ha}=$ grams metallic copper per hectare.

${ }^{\mathrm{z}}$ Two 'Encore' treatments were examined in only 1 year of the study ( $n=4$ replicates); all other areas are means of 8 replicates ( $n=2$ years $\times 4$ replicates). tion than the nontreated trees. In contrast, greater differences in defoliation among treatments were observed on 'Redgold' nectarine (Table 2). Only three of the eight copper treatments, CuALO at 15.1 and $30.2 \mathrm{~g} \mathrm{Cu} / \mathrm{ha}$ and $\mathrm{CuOH}$ at $30.2 \mathrm{~g}$ $\mathrm{Cu}_{\mathrm{m}} / \mathrm{ha}$, had AUDC means that were not significantly different from the nontreated control. At $30.2 \mathrm{~g} \mathrm{Cu}_{\mathrm{m}} / \mathrm{ha}$, no difference in defoliation was observed between $\mathrm{CuALO}$ and $\mathrm{CuOH}$. However, at the higher 60.4 and $90.6 \mathrm{~g} \mathrm{Cu}_{\mathrm{m}} /$ ha rates, $\mathrm{CuOH}$ had significantly less leaf abscission on the nectarine than CuALO. The copper oxychloride product, $\mathrm{COC}$, had defoliation levels that were similar to those of CuALO. Although the peach and nectarine results cannot be compared statistically, six of the eight treatments applied to both cultivars had higher AUDC means on 'Redgold' than on 'Encore'

Copper rate response. Since different concentrations of $\mathrm{CuALO}$ and $\mathrm{CuOH}$ were included in the study, injury and defoliation response curves were generated to allow graphical comparison of the two types of copper-based bactericides (Fig. 3). The relationship between foliar injury and copper concentration was nonlinear on 'Redgold' in both years and on 'Encore' in 2003 (Fig. 3A and B). The amount of injury rose sharply as the copper concentration increased from 0 to $30.2 \mathrm{~g} \mathrm{Cu}_{\mathrm{m}} / \mathrm{ha}$, followed by a less rapid but steady increase as copper levels approached $90.6 \mathrm{~g}$ $\mathrm{Cu}_{\mathrm{m}} / \mathrm{ha}$; the curves resembled a monomolecular growth pattern. In each case, including the somewhat linear response observed on 'Encore' in 2002, the injury response observed for $\mathrm{CuOH}$ was consistently lower than that observed for $\mathrm{CuALO}$. At the single, high rate examined, COC generally caused slightly more injury than either of the other two bactericides. Maximum injury across both years ranged from 27.1 to $65.4 \%$ and from 56.6 to $83.8 \%$ for 'Encore' and 'Redgold', respectively.

In contrast to the injury response, 'Encore' defoliation did not respond to increasing concentration of copper within the range tested (Fig. 3C). Response curves for both $\mathrm{CuALO}$ and $\mathrm{CuOH}$ were near-level, as would be exemplified by a zero slope, ranging from 8.7 to $14.1 \%$ abscised leaves. The only exception was between the two higher concentrations for CuALO in 2002, during which defoliation was observed to increase. Defoliation on 'Redgold' also did not increase between zero and $30.2 \mathrm{~g} \mathrm{Cu}_{\mathrm{m}} / \mathrm{ha}$, ranging between 5 and $10 \%$ abscised leaves (Fig. 3D). However, unlike 'Encore', a dramatic linear increase in defoliation occurred as the copper concentration increased beyond the $30.2 \mathrm{~g} \mathrm{Cu}_{\mathrm{m}} / \mathrm{ha}$ level. Nevertheless, within this higher copper concentration range, less defoliation was observed on trees treated with $\mathrm{CuOH}$ than on those treated with CuALO in both years of the study. 
Fruit size and finish. All treatment main effects were nonsignificant $(P>$ 0.60 ) in the ANOVA of both fruit size dependent variables. Thus, no significant differences in either fruit diameter or weight were observed among fruit harvested from either 'Encore' or 'Redgold' trees treated with different copper-based bactericide types or rates of application (Fig. 4). However, a significant year main effect $(P<0.0001)$ was calculated for both fruit diameter and weight on 'Redgold'. Nectarines harvested in 2003 were approximately $23 \%$ smaller in diameter and about $50 \%$ lower in weight than those harvested in 2002 (Fig. 4C and D). This difference was due to the absence of spring frosts and insufficient hand thinning of fruit in 2003, thereby resulting in a very heavy crop load in that year. Nevertheless, within each year, no statistical difference in fruit size was detected between any of the copper-treated fruit and nontreated fruit.

Fruit scarring was the only discernable fruit finish symptom observed on 'Encore' peach. In 2002, less scarring was visible on the nontreated fruit than on all coppertreated fruit; however, this was not the case in 2003 (Fig. 5A and B). Furthermore, the treatment and year main effects in the ANOVA were not significant $(P>0.57)$, and no differences in fruit scar means were detected among the various copper treatments by the Waller-Duncan procedure. In 2003, soluble solids content of harvested 'Encore' fruit ranged from $12.4 \%$ for fruit treated with $\mathrm{CuOH}$ at $90.6 \mathrm{~g} \mathrm{Cu}_{\mathrm{m}}$ /ha to $14.5 \%$ for the control fruit. However, the treatment effect in the ANOVA was not significant $(P=0.24)$, and no differences among treatment means were identified by the mean comparison procedure.

All five finish symptom categories (scarring, russet, stipple, netting, and off-color) were observed on harvested nectarine fruit in 2002, while all but off-color were detected in 2003 (Fig. 5C and D). The total of all 'Redgold' finish symptoms were on average slightly higher in 2003 (treatment mean $=59.0 \%)$ than $2002(50.2 \%)$. Nevertheless, within each year, none of the treatment main effects were significant $(P$ $>0.17$ ), and no significant differences were detected by the Waller-Duncan procedure among treatment means for any of the five fruit finish symptom categories.

Vegetative shoot growth. All treatment main effects in the ANOVAs for both dependent variables, shoot length and \#nodes/shoot, were nonsignificant $(P>$ 0.26 ). However, the year main effect for shoot length was highly significant $(P<$ 0.0001 ) for both cultivars, indicating a seasonal influence. Mean shoot lengths across all treatments on 'Encore' and 'Redgold' were 46.7 and $47.2 \mathrm{~cm}$ in 2002 versus 40.9 and $41.3 \mathrm{~cm}$ in 2003 , respectively. Apparently, conditions were less conducive to vegetative growth in 2003 .
Nevertheless, no significant differences were observed among copper-based bactericide treatment means or between them and the control for either of the two dependent variables.

Allowable defoliation. Although the 'Encore' trees were larger than the 'Redgold' trees in each of the 2 years of the study, observed leaf densities were much lower in the more vigorous growing 'Encore' (Table 3). Consequently, the mean total number of leaves per tree was quite similar between the two cultivars within each year. Furthermore, the larger number of leaves per tree in 2003 was mostly attributable to growth of the canopy volume as opposed to any increase in foliar density. core' ranged from 13.3 to $48.8 \%$ leaf loss in five of six scenarios (Table 3 ). In comparison, observed defoliation from application of copper-based bactericides was below $15 \%$ abscised leaves for most rates and types of bactericides (Fig. 3C). Thus, after application of copper-based bacteri-
Estimated allowable defoliation on 'En-

cides, sufficient leaves remained on the 'Encore' peach trees to support the proper growth and development of 600 fruit. In contrast, on 'Redgold', only copper rates less than or equal to $30.2 \mathrm{~g} \mathrm{Cu}_{\mathrm{m}}$ /ha allowed sufficient foliage to remain to adequately grow 600 fruit (Fig. 3D); these rates resulted in less than $10 \%$ abscised leaves, and allowable defoliation ranged from 12.9 to $47.7 \%$ leaf loss in five of six scenarios (Table 3). However, application of copper to 'Redgold' at rates above $30.2 \mathrm{~g} \mathrm{Cu}_{\mathrm{m}} / \mathrm{ha}$ may or may not provide sufficient foliage; success at these higher rates was dependent on growing season, the chosen leaf:fruit ratio, and the type of copperbased bactericide applied.

Weather conditions. Environmental data were summarized across all those days beginning with the date of the first bactericide application and ending with the day of the last phytotoxicity assessment. In 2002 and 2003, these experimental periods were 75 and 70 days long, respectively. Mean air temperatures were similar in both years, being $21.0^{\circ} \mathrm{C}$ in 2002 and $22.2^{\circ} \mathrm{C}$ in
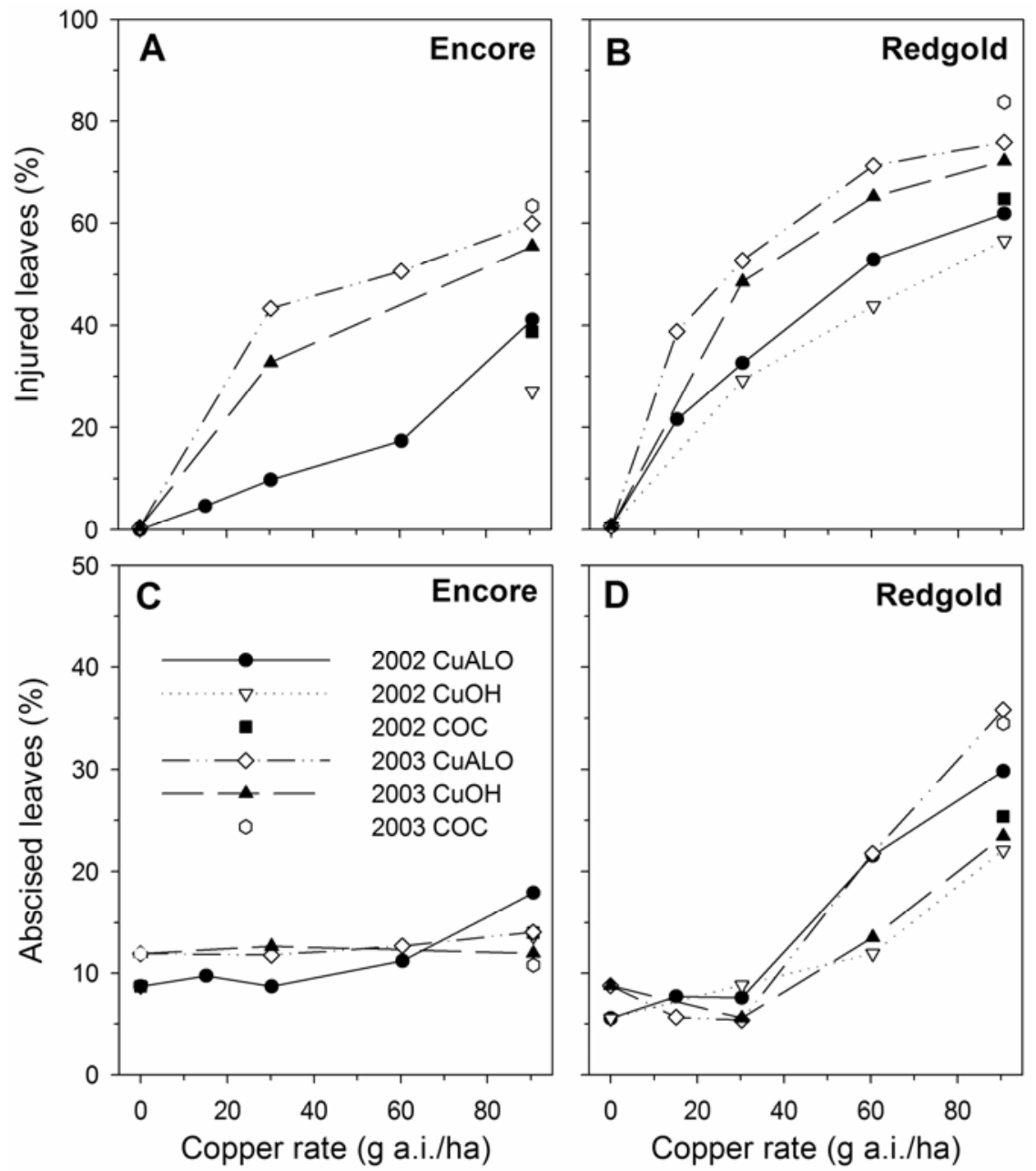

Fig. 3. Effect of copper concentration on foliar injury in $\mathbf{A}$, peach and $\mathbf{B}$, nectarine and on defoliation in $\mathbf{C}$, peach and $\mathbf{D}$, nectarine during two growing seasons. Seven applications of copper-based bactericides were applied at 8- to 15-day intervals beginning at shuck-off. Only one concentration of COC was examined in all studies; only one concentration of $\mathrm{CuOH}$ was examined on 'Encore' in 2002. Data are means of 4 replicate trees assessed on 17 to 19 July 2002 and 6 to 7 August 2003 (final assessment at termination of experiments). 
2003. However, accumulated rainfall was higher (365 versus $272 \mathrm{~mm}$ ); frequency of rain events was greater (32 versus 21); mean daily solar radiation was lower (223 versus $271 \mathrm{Wm}^{2}$ ); and mean relative humidity was higher ( 84.7 versus $73.3 \%$ ) in 2003 versus 2002. Thus, in general, 2003 had a greater percentage of wet, humid, and cloudy days than 2002 .

\section{DISCUSSION}

Seven sequential applications of copperbased bactericides during the 2-month period following bloom were observed to have no effect on size or finish of 'Encore' peach and 'Redgold' nectarine fruit. Even when metallic copper rates were increased to three times that currently applied by commercial growers in New Jersey, no negative effect on fruit growth or finish was observed. Although five types of fruit finish maladies were identified on 'Redgold' nectarine, similar levels of these symptoms were simultaneously observed on nontreated fruit, thereby indicating that copper treatment was not the cause. In particular, application of copper-based bactericides did not augment the russeting of the smooth nectarine epidermis, as previously reported on some cultivars of apple and pear $(13,21)$. Finally, in 2003 we detected no significant effect of copper on soluble solids of 'Encore' peach fruit at harvest; however, results from additional growing seasons are necessary to confirm this finding.

In contrast to our results, a recent report from Australia indicated that application of Bordeaux mixture and copper hydroxide caused significant reductions in fruit weight and fruit diameter of 'Summer Fire' nectarine; significant increase in percentage of russeted 'Ruby Diamond' nectarine; and significant reduction in soluble solids of several plum cultivars (18). This disparity between studies may be due to differences in copper sensitivity among stone fruit species or cultivars, or differences in environmental factors such as rainfall and temperature. However, a total of 16 applications of the copper-based bactericides, five prior to shuck-off and 11 after shuckoff, occurred in this earlier work. Thus, the observed effects on fruit in Australia could
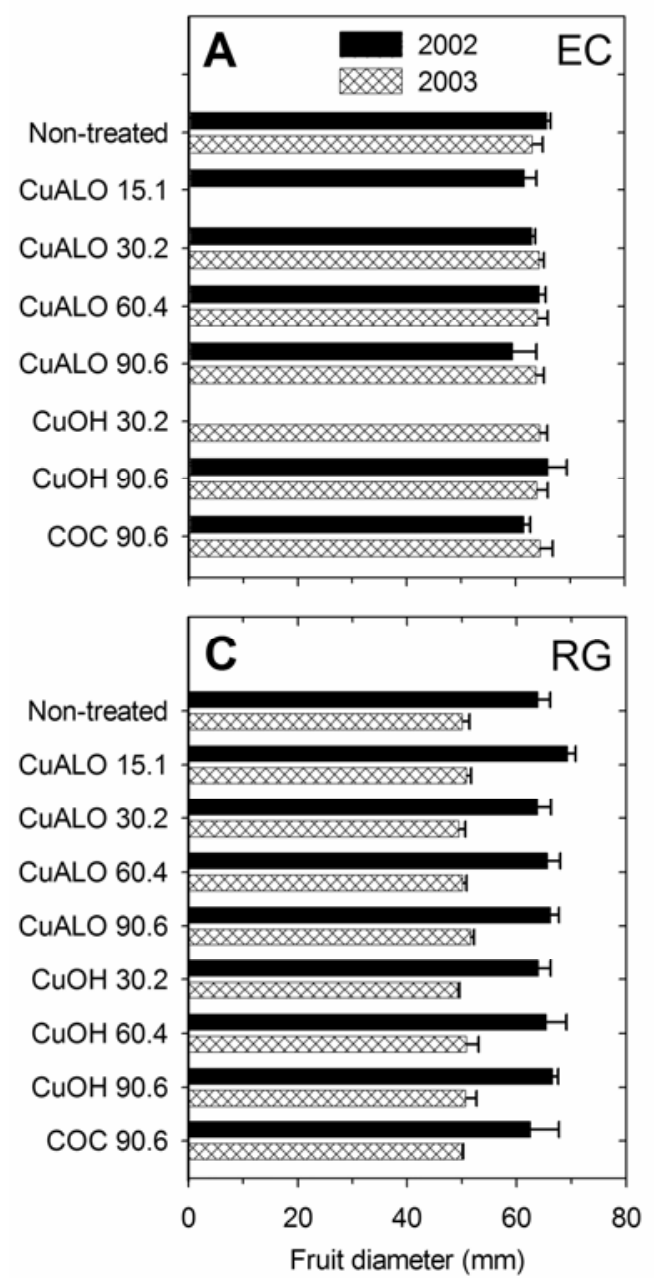
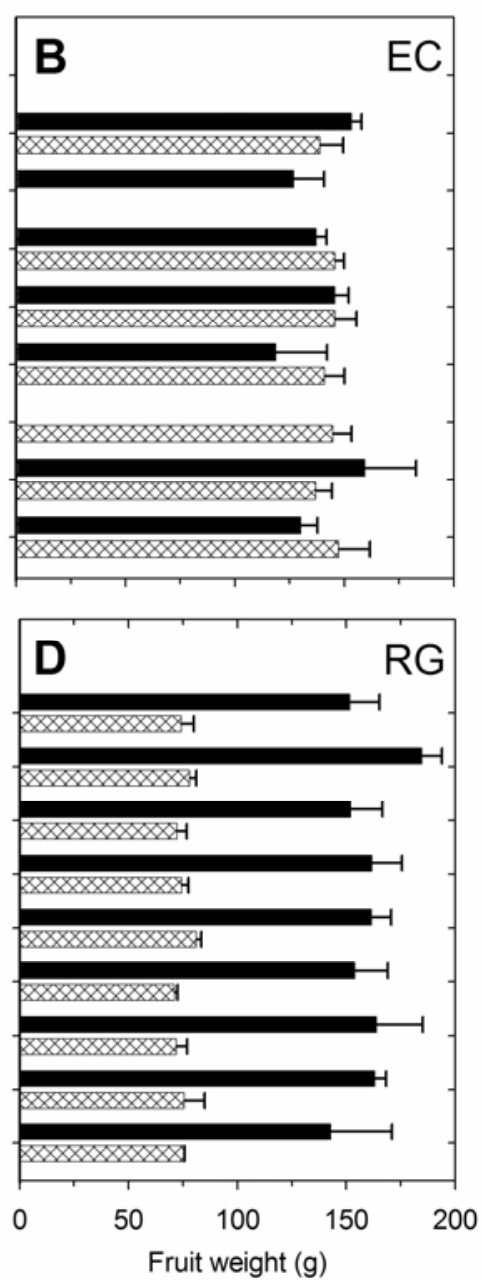

Fig. 4. Effect of copper-based bactericides on fruit size at harvest during two growing seasons for $\mathbf{A}$ and B, 'Encore' peach (EC), and C and D, 'Redgold' nectarine (RG). Seven applications of each bactericide were applied at 8- to 15-day intervals beginning at shuck-off. Within each year, no significant differences in either fruit diameter or weight were observed among treatments on either cultivar $(\alpha$ $=0.05$ ). Data are means of 4 replicate trees at 40 fruit/tree; extension bars represent standard errors.

also be attributed to the additional bactericide applications. Indeed, subsequent research in Australia demonstrated that a reduced spray program, consisting of five pre-shuck-off and four post-shuck-off applications of copper hydroxide, did not significantly decrease fruit size and soluble solids or augment fruit russet of seven plum cultivars, one nectarine cultivar, and one peach cultivar (17).

The inorganic bactericides copper hydroxide and copper oxychloride were not found to be more phytotoxic to peach or nectarine foliage than the organometallic Tenn-Cop standard, a mixture of copper abietate, copper linoleate, and copper oleate. Phytotoxic injury and defoliation response were similar across a wide range of concentrations of the tested materials. Statistical analyses of the phytotoxicity progression curves revealed that copper hydroxide tended to be less phytotoxic than either the organometallic bactericide or copper oxychloride. These results, along with the successful testing of copper hydroxide in Australia (17), indicate that these inorganic copper-based bactericides can be used safely during the postbloom cover spray period. However, additional fixed copper compounds, such as basic copper sulfate, need to be examined to determine if inorganic coppers as a class are at least equivalent in phytotoxicity to the organometallic standard currently used by growers.

In general, 'Redgold' nectarine was observed to be more sensitive to copper injury than 'Encore' peach. Although copper did not influence fruit growth or damage the finish of either cultivar, foliar injury and defoliation were consistently greater on the nectarine. This difference between cultivars was particularly evident as the concentration of metallic copper increased above $30.2 \mathrm{~g} / \mathrm{ha}$. Perhaps most importantly, 'Encore' peach was highly resistant to defoliation from copper, regardless of the concentration of copper applied or the type of bactericide utilized. Defoliation on 'Encore' exceeded $10 \%$ only after six of the total seven applications of bactericide, whereas leaf abscission on 'Redgold' exceeded this threshold after only two applications. Thus, these results appear to indicate that peach is less sensitive than nectarine with respect to foliar injury. However, additional comparative studies on other peach and nectarine cultivars are required to validate this generalization, as well as to determine the range of copper sensitivity among cultivars.

Although copper-based bactericides did not have a direct effect on fruit quality, defoliation from copper could influence yield by reducing the total photosynthetic capacity of a tree. If the crop load is too high for the number of remaining leaves, then yield may be reduced by a reduction in fruit size, a phenomenon similar to inadequate thinning $(6,20)$. In our study, we observed no effect of defoliation on fruit 
size for either cultivar. On 'Encore' peach, this result could be explained by the low level of copper-induced defoliation (mostly below 15\%); more than enough leaves remained attached to grow the fruit. However, on 'Redgold' nectarine, foliar abscission levels were much higher, ranging from 5 to $35 \%$. Estimation of the number of leaves on 'Redgold' trees indicated that allowable defoliation could be as high as
35 to $48 \%$ without having any effect on fruit growth, assuming a leaf:fruit ratio of 30 and a crop load of 600 fruit. But at higher leaf:fruit ratios, this theoretical explanation was inadequate; allowable defoliation was estimated to be less than that observed on trees treated at the higher copper concentrations.

Several other factors may explain why defoliation did not influence fruit size.
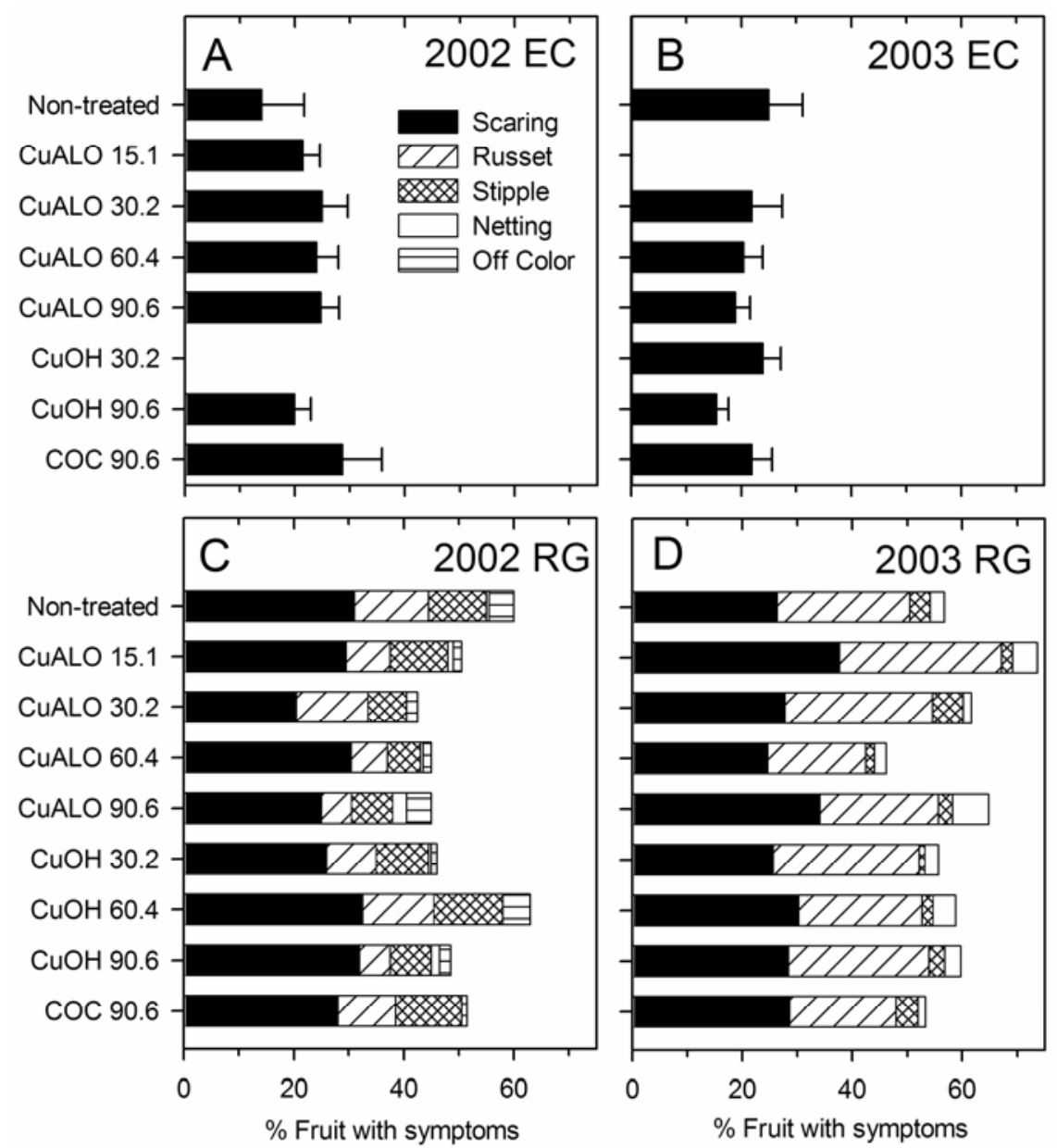

Fig. 5. Effect of copper-based bactericides on fruit finish at harvest during two growing seasons for $\mathbf{A}$ and B, 'Encore' peach (EC), and $\mathbf{C}$ and $\mathbf{D}$, 'Redgold' nectarine (RG). Seven applications of each bactericide were applied at 8- to 15-day intervals beginning at shuck-off. Within each year, no significant differences in any category were observed among treatments on either cultivar $(\alpha=0.05)$; only scarring was observed on peach. Data are means of 4 replicate trees at 40 fruit/tree; extension bars represent standard errors.

New, uninjured leaves created throughout the season, as part of normal shoot growth and development, offset the loss of leaves from copper injury. Thus, the percentage of abscised leaves increased gradually over time. Had $35 \%$ of the leaves been missing from shuck-off onward, then defoliation may well have impacted fruit growth. Also, since several bactericide applications were required before leaves abscised, defoliation by the copper treatments progressed from the shoot base outward toward the terminal bud. Thus, older, typically shaded leaves were removed first, and studies have shown that peach leaves in partial shade have lower photosynthetic efficiency than those in higher light (9). In addition, removal of foliage allowed better light penetration into the canopy, thereby increasing the photosynthetic activity of the remaining leaves. Finally, since both 'Encore' and 'Redgold' are late-ripening cultivars, their fruit had most of the season to grow and develop. In contrast, had an early-ripening cultivar been used, fruit size may have been affected by defoliation since these fruit must develop more quickly. Each of these factors separately or in conjunction may have helped to lessen the impact of the observed defoliation on fruit growth, particularly on the nectarine.

The influence of environmental conditions on plant growth and copper phytotoxicity of the foliage was apparent when comparing each of the two growing seasons. The frequently wet, cloudy weather in 2003, which averaged one rainfall event every 2 days, resulted in shorter vegetative shoots and fewer leaves per shoot relative to that observed in 2002. These same rainy periods in 2003 most likely augmented the movement of copper residues (ions and/or compounds) into the leaves, thereby causing the higher levels of foliar injury on both cultivars in that year. However, based on the analyses of variance for the year main effect, this significant increase in foliar injury between seasons did not translate into a significant increase in defoliation for either cultivar. It is entirely conceivable that the same frequent rains, which may have enhanced copper entry into plant tissue, also lowered overall

Table 3. Estimation of allowable defoliation from tree volume and foliar density measurements on nontreated peach and nectarine trees for three levels of fruit to leaf ratios during the 2002 and 2003 growing seasons

\begin{tabular}{|c|c|c|c|c|c|c|c|c|c|c|}
\hline \multirow[b]{3}{*}{ Cultivar } & \multirow[b]{3}{*}{ Year } & \multicolumn{3}{|c|}{ Tree canopy characteristics ${ }^{x}$} & \multirow{2}{*}{\multicolumn{3}{|c|}{$\begin{array}{l}\text { Maximum fruit loady } \\
\text { (fruit/tree) } \\
\text { leaf:fruit ratio }\end{array}$}} & \multirow{2}{*}{\multicolumn{3}{|c|}{$\begin{array}{l}\text { Allowable defoliation } \\
\text { ( } \% \text { leaf loss) } \\
\text { leaf:fruit ratio }\end{array}$}} \\
\hline & & \multirow{2}{*}{$\begin{array}{c}\text { Tree } \\
\text { volume } \\
\left(\mathbf{m}^{3}\right)\end{array}$} & \multirow{2}{*}{$\begin{array}{c}\text { Leaf } \\
\text { density } \\
\left(\mathbf{l v s} / \mathrm{m}^{3}\right)\end{array}$} & \multirow{2}{*}{$\begin{array}{c}\text { Leaf } \\
\text { total } \\
\text { (lvs/tree) }\end{array}$} & & & & & & \\
\hline & & & & & 30 & 40 & 50 & 30 & 40 & 50 \\
\hline \multirow[t]{2}{*}{ Encore } & 2002 & 30.99 & 896.7 & 27,674 & 922 & 692 & 554 & 35.0 & 13.3 & -8.4 \\
\hline & 2003 & 43.41 & 808.0 & 35,151 & 1,172 & 879 & 703 & 48.8 & 31.7 & 14.7 \\
\hline \multirow[t]{2}{*}{ Redgold } & 2002 & 28.73 & 938.7 & 27,630 & 921 & 691 & 553 & 34.9 & 13.1 & -8.6 \\
\hline & 2003 & 36.79 & 943.8 & 34,443 & 1,148 & 861 & 689 & 47.7 & 30.3 & 12.9 \\
\hline
\end{tabular}

${ }^{\mathrm{x}}$ Tree volumes and leaf totals are means of the four nontreated replicate trees located within each test block; leaf densities are means of six randomly located measurements per tree.

${ }^{y}$ Maximum fruit load, calculated by dividing the leaf total by the leaf:fruit ratio, assumes all leaves are utilized to produce fruit.

${ }^{\mathrm{z}}$ The calculation of allowable defoliation assumed that trees are thinned to 600 fruit, and therefore required 18,000, 24,000, and 30,000 leaves/tree for the three desired leaf:fruit ratios of 30, 40, and 50 leaves/fruit, respectively. 
residues by increasing the potential for wash off.

The results of this study showed that inorganic copper hydroxide and copper oxychloride compounds can be safely applied to peach during the postbloom period of the growing season. Although the nectarine cultivar was more prone to foliar injury, applications at rates equivalent to the current organometallic standard appear feasible. The results of this study, however, do not address whether or not these inorganic copper-based bactericides will be effective at controlling bacterial spot on fruit during the postbloom period. For example, if the lower phytotoxicity exhibited by copper hydroxide is due to a lower availability of active copper residue, then efficacy against the pathogen may also be diminished. Conversely, a slower release of copper ions by these bactericides may provide longer residual action and better disease control.

Some recent results appear to indicate that inorganic coppers can provide effective postbloom bacterial spot control. Under low disease pressure, a targeted copper hydroxide program yielded significant reductions in fruit infection on plum in Australia (17). Similarly, recent results on peach showed that basic copper sulfate provided effective control of bacterial spot under moderate disease pressure (12). However, complete failure of chemical control programs on peach is not uncommon on highly susceptible cultivars grown under favorable environmental conditions $(14,16)$. Similar control failures have also been observed commercially, particularly on some of the newer, more susceptible cultivars.

The results of our study indicated that higher application rates of copper, above the current maximum of $30.2 \mathrm{~g} \mathrm{Cu}_{\mathrm{m}} / \mathrm{ha}$, should be possible for management of bacterial spot on highly susceptible peach cultivars without any loss of fruit quality or yield. Thus, research is needed to determine if the application of additional copper, particularly copper hydroxide, improves bacterial spot control on these cultivars. Furthermore, since these inorganic copper compounds also provide fungicidal activity, research is needed to determine their activity against several fungal diseases that occur simultaneously during the postbloom period. Of particular interest are peach scab, caused by Cladosporium carpophilum, and anthracnose, caused by Colletotrichum acutatum and C. gloeosporioides (2,7). Even if control of these fungal diseases was only par- tial, such activity may allow a reduction in the amount of the fungicides commonly used during the postbloom period. However, in implementing greater commercial usage of copper, consideration should be given to the long-term impact of copper residues on soil microbiota (22).

Given that copper-based bactericides induce foliar injury, cultivar and rootstock vigor, pruning practices, and fertilization programs also need to be investigated, as these factors may play an important role in maintaining adequate photosynthetic capacity. Furthermore, since the trees in our study were relatively young and vigorous, similar experimentation on older or stressed trees needs to be conducted. Finally, the long-term effects of a high rate copper program on overall tree health, particularly with respect to winter hardiness, should be examined.

\section{ACKNOWLEDGMENTS}

This research was funded by the Pennsylvania Department of Agriculture, Peach and Nectarine Research Program Board, the New Jersey Agricultural Experiment Station, and NuFarm Americas, Inc. We thank J. Veler and K. A. Stoms for their technical assistance.

\section{LITERATURE CITED}

1. Anderson, H. W. 1956. Diseases of Fruit Crops. McGraw-Hill Book Company, New York.

2. Bernstein, B., and Miller, R. W. 1995. Anthracnose. Pages 18-19 in: Compendium of Stone Fruit Diseases. J. M. Ogawa, E. I. Zehr, G. W. Bird, D. F. Ritchie, K. Uriu, and J. K. Uyemoto, eds. American Phytopathological Society, St. Paul, MN.

3. Childers, N. F., Morris, J. R., and Sibbett, G. S. 1995. Modern Fruit Science, Orchard and Small Fruit Culture. Horticultural Publications, Gainesville, FL.

4. Goto, M. 1990. Fundamentals of Bacterial Plant Pathology. Academic Press, New York.

5. Hamilton, G. C., Heckman, J. R., Lalancette, N., Majek, B. A., and Shearer, P. W. 2006. New Jersey Commercial Tree Fruit Production Guide, Gail R. W. Lokaj, ed. Rutgers University, Coop. Ext. Bull. E002.

6. Havis, A. L. 1962. Effects of time of fruit thinning of 'Redhaven' peach. Proc. Am. Soc. Hortic. Sci. 80:172-176.

7. Hendrix, F. F., Jr. 1995. Scab. Pages 11-12 in: Compendium of Stone Fruit Diseases. J. M. Ogawa, E. I. Zehr, G. W. Bird, D. F. Ritchie, K. Uriu, and J. K. Uyemoto, eds. American Phytopathological Society, St. Paul, MN.

8. Johnson, S., and Larsen, R. P. 1971. Peach Culture in Michigan. Cooperative Extension Service, Michigan State University, Ext. Bull. 509.

9. Kappel, F., and Flore, J. A. 1983. Effect of shade on photosynthesis, specific leaf weight, leaf chlorophyll content, and morphology of young peach trees. J. Am. Soc. Horic. Sci. 108:541-544.

10. Lalancette, N., and Foster, K. A. 2004. Phyto- toxicity of copper bactericides to peach and nectarine. (Abstr.) Phytopathology 94:S56

11. Lamb, R. C., and Edgerton, L. J. 1976. Peach Growing. New York State Cooperative Extension, Cornell University, Inform. Bull. 44.

12. Ngugi, H. K., Brannen, P. M., Watson, T., and Scherm, H. 2004. Evaluation of alternatives to oxytetracycline for control of bacterial spot of peach during the cover sprays, 2004. Fungicide and Nematicide Tests 60:STF009. American Phytopathological Society, St. Paul, MN.

13. Reil, W. O., Beutel, J. A., and Moller, W. J. 1973. Fireblight - Effects of control sprays on russeting of Bartlett pears. Calif. Agr. 27(6):56.

14. Ritchie, D. F. 2004. Evaluation of copper materials to control bacterial spot on highly susceptible peach, 2003. Fungicide and Nematicide Tests 59:STF010. American Phytopathological Society, St. Paul, MN.

15. Ritchie, D. F. 1995. Bacterial spot. Pages 5052 in: Compendium of Stone Fruit Diseases. J. M. Ogawa, E. I. Zehr, G. W. Bird, D. F. Ritchie, K. Uriu, and J. K. Uyemoto, eds. American Phytopathological Society, St. Paul, $\mathrm{MN}$.

16. Scherm, H., Savelle, A. T., Cook, M. J., IV, Reilly, C. C., and Hotchkiss, M. W. 2006. Evaluation of alternatives to oxytetracycline for control of bacterial spot of peach during the cover sprays, 2005. Fungicide and Nematicide Tests 61:STF010. American Phytopathological Society, St. Paul, MN.

17. Stephens, P., and Cameron, D. 2003. Control of bacterial spot in stone fruit using targeted copper applications. Summerfruit Aust. Quart. 5(2):8-9.

18. Stephens, P., Cameron, D., and McLachlan, K. 2002. Control of bacterial spot in plums achieved using a new copper based spray program, but some detrimental effects reported. Summerfruit Aust. Quart. 4(2):17-19.

19. Thomson, W. T. 2000. Agricultural Chemicals, Book IV - Fungicides. Thomson Publications, Fresno, CA.

20. Tukey, H. B., and Einset, O. 1938. Effect of fruit thinning on size, color, and yield of peaches and on growth and blossoming of the tree. Proc. Am. Soc. Hortic. Sci. 36:314-319.

21. van der Zwet, T., and Keil, H. L. 1979. Fire Blight, A Bacterial Disease of Rosaceous Plants. U.S. Dep. Agric., Agric. Handb. No. 510.

22. Van-Zwieten, L., Merrington, G., and VanZwieten, M. 2004. Review of impacts of soil biota caused by copper residues from fungicide application. SuperSoil 2004: Proc Aust. N.Z. Soils Conf., 3rd. University of Sydney, Australia. Online publication, www.regional. org.au/au/asssi/.

23. Weinberger, J. H. 1932. The relation of leaf area to size and quality of peaches. Proc. Am. Soc. Hortic. Sci. 28:18-22.

24. Werner, D. J., Ritchie, D. F., Cain, D. W., and Zehr, E. I. 1986. Susceptibility of peaches and nectarines, plant introductions, and other Prunus species to bacterial spot. HortScience 21:127-130.

25. Wu, B. H., Ben Mimoun, M., Genard, M., Lescourret, F., Besset, J., and Bussi, D. 2005. Peach fruit growth in relation to the leaf-tofruit ratio, early fruit size and fruit position. J. Hortic. Sci. Biotechnol. 80:340-345. 